\title{
EXTRACTION OF TOTAL PHENOLIC CONTENT AND ANTIOXIDANT ACTIVITY OF Capsicum chinense AND Capsicum spp IN DIFFERENT SOLVENTS AND EXTRACTION TIME
}

\author{
EXTRAÇÃO DO CONTEÚDO DE FENÓLICOS TOTAIS E ATIVIDADE \\ ANTIOXIDANTE DE Capsicum chinense E Capsicum spp EM DIFERENTES \\ SOLVENTES E TEMPO DE EXTRAÇÃO
}

\section{Michelly da Silva RIBEIRO ${ }^{1}$; Claudia Maria Tomás MELO²; Eduardo Santos ALMEIDA²; Carla Regina Amorim dos Anjos QUEIROZ ${ }^{2}$}

1. Graduada em Tecnologia em Alimentos pelo IFTM, Campaus Uberlândia, Uberlandia, MG, Brasil; 2. professores'doutores IFTM- Uberlandia, MG, Brasil, 3. Técnico de laboratório - IFTM, Uberlandia, MG, Brasil claudiamelo@iftm.edu.br

\begin{abstract}
The purpose of this work was to evaluate the extraction and quantification of total phenolic compounds and the antioxidant activity of two peppers processed by four different methods (in natura, dried, preserved in vinegar and preserved in oil). The extraction efficiency of total phenolics using seven solvents (distilled water, ethanol, 50\% ethanol, methanol, 50\% methanol, ketone p.a and 50\% ketone) were checked. Total phenolic analyzes were performed using the Folin-Ciocalteu and gallic acid method to obtain the standard curve with $650 \mathrm{~nm}$ absorbance reading. The antioxidant activity was determined using a spectrophotometric method using the reagent 2,2-diphenyl-1-picryl hydrazyl (DPPH). No significant differences were observed in the two extraction times 6 and $24 \mathrm{~h}$. For samples preserved in vinegar, no significant differences were observed between the solvents used for the extraction. The Capsicum chinense pepper showed the highest amount of phenolic compounds in all treatments when compared to the chili pepper, except when conserved in oil. For the dry pepper, the lowest total phenolic extraction value was obtained with 99.5\% ethanol (p.a.) and acetone p.a ACS 99.5\% (p.a.), which differed from the peppers preserved in oil. The analysis of the antioxidant activity of Capsicum chinense and Capsicum spp did not present a significant difference $(\mathrm{p}>0.05)$ when compared to the dried or vinegar preserved samples. However, the sample of Capsicum chinense pepper in natura presented higher antioxidant activity than the samples conserved in oil. It can be considered from the experimental results that the peppers in this study, especially in fresh and dried form are good sources of natural antioxidants.
\end{abstract}

KEYWORDS: Chemical analysis. Pepper.

\section{INTRODUCTION}

Currently, people have shown an increasing tendency to consume products with functional properties, because it has been reported that they are beneficial to human health. These reported benefits such as curative and preventive potential are attributable to the presence of compounds with antioxidant properties. Benefits of consuming the antioxidant compounds present in foods of plant origin are already known. Some researchers have studied and quantified phenolic compounds and antioxidant activity in foods of plant origin such as vegetables and fruits (OLIVEIRA et al., 2009; VELIOGLU et al., 1998), medicinal plants (DALLAQUA; DAMASCENO, 2011), and seasonings (MORAIS et al., 2009).
Antioxidant compounds can neutralize free radicals, which are atoms or molecules formed by the body during metabolism that might trigger physiopathological processes such as aging, cancer, atherosclerosis, inflammation, and Alzheimer's disease. Normal levels of reactive species are essential to maintain cellular homeostasis because they act as messengers in the signaling pathways involving insulin, growth hormones, and cytokines. In addition, they also act as messengers in pathways that regulate antioxidant enzyme activity or control the expression of some gene families such as those involved in mitochondrial metabolism (HEKIMI et al., 2011; LAMBETH; NEISH, 2014).

Therefore, the consumption of substances with antioxidant capacity in the diet may be of great benefit in the prevention and treatment of diseases associated with increased oxidative stress. 
Furthermore, these substances may also be extracted and added to foods as sources of natural antioxidant.

Peppers also have antioxidant properties which are mainly owing to the presence of essential oils. (PAULA et al., 2010). Valverde (2011) performed a study investigating several physicochemical parameters of in natura and pickled chili peppers (Capsicum frutescens L). Oliveira (2011) performed chemical characterization and assessed in vitro antioxidant as well as antifungal activities of four pepper species, $C$. baccatum var. pendulum ("dedo de moça"), $C$. chinense ("de cheiro"), C. chiniense ("de cheiro ardida"), and $C$. frutescens (chili pepper). Melo et al. (2011) quantified the phenolic compounds and determined the antioxidant activity of three pepper cultivars ("bode," "cumari," and "chili"). According to Pinto et al. (2013), peppers have antiinflammatory, hypocholesterolemic, and analgesic properties, which are probably owing to the presence of capsaicinoids, vitamins, and polyphenols and these properties are considered beneficial to human health.

Seasonings such as pepper are widely valued in the culinary world and its pigments, aromas, and pungent substances are used in industry. Peppers have short production cycle and are rich in vitamins $\mathrm{C}$ and $\mathrm{B}$ complex, flavonoids, carotenoids, and other secondary metabolites with natural antioxidant properties. Considering that there are several forms available to consumers including powdered (black pepper), in natura, whole or pickled in preservatives, it is important to determine if the food processing method leads to a loss of compounds with antioxidant properties (PINTO et al., 2013). The pungent and spicy characteristics of peppers are attributable to the presence of capsaicin, which has antioxidant activity and occurs in different amounts in the seeds and fruits of plants (LUTZ; FREITAS, 2008). Capsaicin is one of the sources of phenolic compounds present in peppers and Costa et al. (2010) makes the quantification separately of capsaicin and total phenolics showing, therefore, how this compound varies in diferent species of peppers, besides making a study of which solvent is more efficient in the extraction of this compound

In the extraction process, different solvents and different extraction times can be used, but it is necessary to identify the solvent and the time with the highest extraction potential and low cost, that is, analyze the cost / benefit, which may be specific for each type of evaluated compound. In this context, this study aimed to extract phenolic compounds from two pepper cultivars using seven solvents and two extraction times. In addition, we sought to quantify the total phenolic contents and determine the antioxidant activity of peppers that had been dried, pickled, or were in natura. The Capsicum chinens ("bode vermelha") and Capsicum spp ("cheiro") were chosen for the research because they are common in the country and in the region of the Triângulo Mineiro, making it easy to access and low cost and therefore interesting to explore the potential of these species.

\section{MATERIAL AND METHODS}

Two-hundred grams of Capsicum chinens ("bode vermelha") and Capsicum spp ("cheiro") peppers were acquired from the Centrais de Abastecimento S.A. of Uberlândia (CEASA) in three collections, which were stored at the Laboratory for Physicochemical Analysis of the Federal Institute of Triângulo Mineiro. The analyzes were performed in triplicate. The fruits of both peppers were mature at the time of purchase. The peppers were stored in a refrigerator at $\pm 8{ }^{\circ} \mathrm{C}$ during the procedure of analysis that last 5 days.

\section{Preparation of phenolic extract}

The peppers were washed in running water to remove impurities. To obtain extracts $1.0000 \mathrm{~g}$ of fruit crushed or mashed fruit was weighed into beakers of $100 \mathrm{~mL}$ and added to $30.00 \mathrm{~mL}$ of solvent of the extracting solvent to be tested. The extraction was performed in two-time periods, 6 and $24 \mathrm{~h}$ at room temperature ranging from 28 to $32{ }^{\circ} \mathrm{C}$. The samples in extraction were shaken sporadically, according to Bertoldi (2006), with modifications.

The extracts of the two varieties were obtained using 7 different solvents (deionized water, ethanol, acetone and methanol) in p.a. form and diluted to $50 \%$, with deionized water. Four treatments were performed: treatment 1 (T1) was composed of fresh peppers; in treatment 2 (T2) the peppers underwent a bleaching process, which consisted of leaving them boiled for 2 minutes and then prepared as canned in oil. For treatment 3 (T3) the same procedure was done, but the canning was made in vinegar. The preserves were stored for 180 days before analysis of the phenolic compounds and antioxidant activity. Treatment 4 (T4) consisted of dried peppers at $60{ }^{\circ} \mathrm{C}$ for $48 \mathrm{~h}$ in an air circulation oven. Three replicates of each experiment were performed.

The extraction and determination of the phenolic compounds were performed according to the flowchart in Figure 1. 


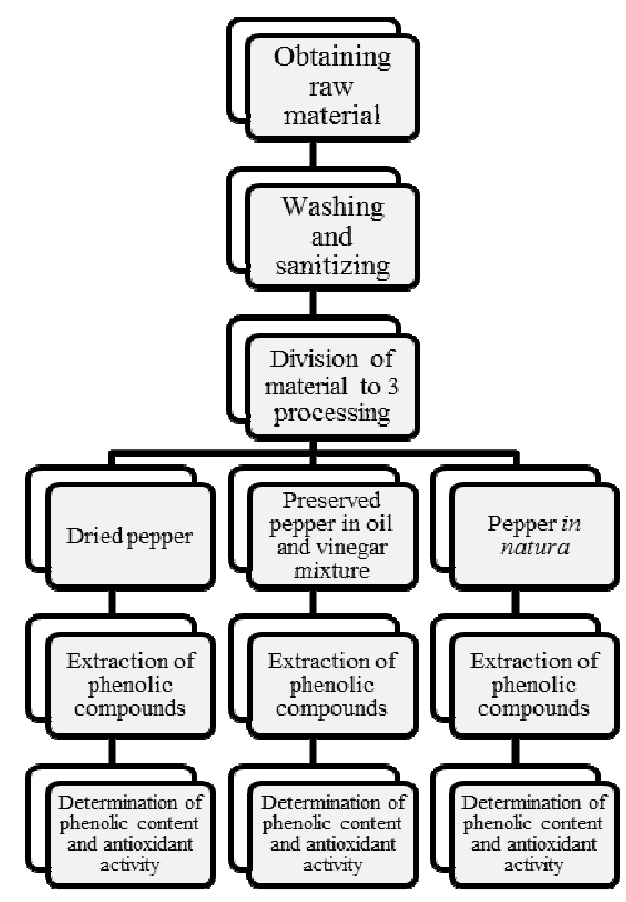

Figure 01. Flowchart showing sample preparation until analysis.

\section{Determination of total phenolic and antioxidant activity}

Analyses of the total phenolic content were performed according to Swain and Hillis (1959) and Oliveira et al. (2009). The amount of phenols in each extract was quantified by means of a standard calibration curve prepared with gallic acid at concentrations of $0.5,10,15,20,25$ and $30 \mu \mathrm{g} / \mathrm{mL}$. To each of the concentrations was added $2.5 \mathrm{~mL}$ of $10 \% \mathrm{v} / \mathrm{v}$ Folin-Ciocalteau and $2.0 \mathrm{~mL}$ of freshly prepared $7.5 \% \mathrm{w} / \mathrm{v}$ sodium carbonate. Absorbance measurements were performed at the wavelength of $760 \mathrm{~nm}$. Together with these measurements, a blank was made, replacing the extract with distilled water. The concentration of the phenolic compounds was calculated by the equation of the line, expressed as milligram of gallic acid equivalents per gram of pepper (mg EAG/g). The extract was filtered and $0.5 \mathrm{~mL}$ was pipetted and transferred to test tubes. $2.5 \mathrm{~mL}$ of $10 \% \mathrm{v} / \mathrm{v}$ Folin-Ciocalteau and $2.0 \mathrm{~mL}$ of $7.5 \% \mathrm{w} / \mathrm{v}$ sodium carbonate were added to each tube. The reading was performed at room temperature in a spectrophotometer with absorbance at $760 \mathrm{~nm}$ against a blank.

The antioxidant activity was assessed using a spectrophotometric method with the 2,2-diphenyl1-picrylhydrazyl (DPPH) reagent. The DPPH method is based on the percentage of decrease in absorbance caused by the extract, as determined by reading the absorbance of the samples using a spectrophotometer at $517 \mathrm{~nm}$ (BRAND-WILLIAMS et al., 1995; MEDA et al., 2005). In this reaction, the DPPH species are reduced by the antioxidant constituents present in organic compounds (MORAIS et al., 2009).

For the evaluation of the free radical DPPH activity (1,1-diphenyl-2-picrylhydrazine), aliquots of $0.5 \mathrm{~mL}$ of pepper extracts were added to $1.0 \mathrm{~mL}$ of DPPH $1 \times 10^{-3}$ mol. $\mathrm{L}^{-1}$ and $2.0 \mathrm{~mL}$ of methanol was added. After 90 minutes incubation at room temperature and sheltered from light, the DPPH free radical reduction was measured by reading the absorbance at the wavelength of $517 \mathrm{~nm}$ against a specific blank.

Samples (extracts) were read directly without the need to prepare the calibration curve. The ability to free radical sequestration was expressed as a percentage of radical oxidation inhibition, according to Equation 01. The scavenging activity percentage (AA\%) was determined according to Mensor et al. (2001)

$\% \mathrm{AA}=100 *(\mathrm{Aa}-(\mathrm{Ab}-\mathrm{Ac})) /(\mathrm{Aa})$

Eq $(01)$

(MENSOR et al., 2001)

Where: $\mathrm{Aa}=$ absorbance of the DPPH + methanol solution;

\section{DPPH}

$$
\mathrm{Ab}=\text { absorbance of the extract }+ \text { methanol }+
$$

$\mathrm{Ac}=$ absorbance of the extract + methanol

AA\% $=$ scavenging activity percentage 
Data underwent variance analysis (ANOVA) at a $5 \%$ significance level. Subsequently, means were compared by the Tukey's test through ASSISTAT software (SILVA; AZEVEDO, 2002).

\section{RESULTS AND DISCUSSION}

Considering in natura peppers (Table 1), the solvents used in the total phenolic extraction showed significant differences $(\mathrm{p}<0.05)$ and, excluding water, had total phenolic content of 1.43 $\mathrm{mg} \mathrm{GAE} / \mathrm{g}$.

For the dried pepper, the lowest phenolics extraction mean value occurred with ethanol p.a. and acetone p.a. solvents. The remaining solvents showed a mean phenolic content of $4.90 \mathrm{mg} \mathrm{GAE} / \mathrm{g}$. In oil, it was observed that the highest mean value is for ethanol p.a. and acetone p.a ( $3.84 \mathrm{mg}$ $\mathrm{GAE} / \mathrm{g})$.. For vinegar, the solvent extraction capacity did not differ significantly. (0.49 mg GAE/g) .

Table 01. Phenolic content expressed as milligrams of gallic acid equivalents per gram (mg GAE/g) from seven different solvent extracts, obtained from the mean of Capsicum chinense and Capsicum ssp.

\begin{tabular}{ccccc}
\hline Solvent & in natura $^{*}$ & dry & oil $^{* * *}$ & T3 \\
T2 & $1.04 \mathrm{~b}$ & $5.23 \mathrm{a}$ & $0.90 \mathrm{~b}$ & $0.52 \mathrm{a}$ \\
Distilled water & $1.27 \mathrm{ab}$ & $2.09 \mathrm{~b}$ & $3.83 \mathrm{a}$ & $0.49 \mathrm{a}$ \\
ethanol p.a & $1.38 \mathrm{ab}$ & $5.44 \mathrm{a}$ & $0.84 \mathrm{~b}$ & $0.44 \mathrm{a}$ \\
ethanol 50\% v/v & $1.29 \mathrm{ab}$ & $1.92 \mathrm{~b}$ & $3.85 \mathrm{a}$ & $0.76 \mathrm{a}$ \\
acetone p.a & $1.76 \mathrm{a}$ & $4.62 \mathrm{a}$ & $0.99 \mathrm{~b}$ & $0.46 \mathrm{a}$ \\
acetone 50\% v/v & $1.54 \mathrm{ab}$ & $4.04 \mathrm{a}$ & $1.56 \mathrm{~b}$ & $0.38 \mathrm{a}$ \\
methanol p.a & $1.32 \mathrm{ab}$ & $5.18 \mathrm{a}$ & $0.69 \mathrm{~b}$ & $0.36 \mathrm{a}$
\end{tabular}

${ }^{* *}, *$, ns Significant difference at $1 \%$ probability level $(\mathrm{p}<0.01)$, at $5 \%$ probability level $(0.01<\mathrm{p}<0.05)$ and no-significant difference by analysis of variance; Same letters in the same column do not differ ( $\mathrm{p}>0.05)$ by Tukey test.

Boeing et al. (2014) studied the effect of solvents on extraction of total phenols in anthocyanins from cranberry and strawberry and observed that a mixture of acetone/water (70/30, $\mathrm{v} / \mathrm{v})$ was highly efficient, this observation led to the conclusion that the extraction step is affected considerably by the solvent combination. They also observed a good correlation between the total phenolic content and antioxidant capacity of the extracts analyzed, which agrees with studies by Santas et al. (2008) who reported a similar correlation. Costa et al. (2010) studied the extraction of capsaicin and total phenolics in four species of peppers and found that chloroform was the most efficient. From the studies proposed in the literature it is verified that there is no standard solvent for the extraction of phenolic compounds and that there is therefore a need to perform studies of the best solvent for extracting. The extraction efficiency of different solvents is related to the characteristics of the food and / or the chemical compounds.

The Capsicum chinense "bode vermelha" pepper had the highest phenolic content at all treatment conditions except for preservation in oil, compared with the Capsicum spp "de cheiro" pepper, which showed no significant difference between sample treatments (Table 2). The lowest total phenolic values were observed in the vinegarpreserved samples, indicating that various methods of preparing peppers for consumption may differentially influence the amount of total phenols retained in the final product.

Table 2. Mean phenolic content expressed as milligrams of gallic acid equivalents per gram $(\mathrm{mg} \mathrm{GAE} / \mathrm{g})$ in Capsicum chinense and Capsicum spp peppers, according to a mean obtained from the seven solvents.

\begin{tabular}{ccccc}
\hline Peppers & In natura $^{* *}$ & Dry $^{* *}$ & Oil $^{* *}$ & Vinegar $^{* *}$ \\
\hline Capsicum chinense & $1.63 \mathrm{a}$ & $4.60 \mathrm{a}$ & $1.92 \mathrm{a}$ & $0,64 \mathrm{a}$ \\
Capsicum spp & $1.12 \mathrm{~b}$ & $3.54 \mathrm{~b}$ & $1.73 \mathrm{a}$ & $0,33 \mathrm{~b}$ \\
\hline
\end{tabular}

${ }^{* *}, *$, ns Significant difference at $1 \%$ probability level $(\mathrm{p}<0.01)$, at $5 \%$ probability level $(0.01<\mathrm{p}<0.05)$ and no-significant difference by analysis of variance; Same letters in the same column do not differ $(p>0.05)$ by Tukey test. 
Costa et al. (2010) obtained phenolic concentrations of 177.63 and $177.19 \mathrm{mg} \mathrm{GAE} / 100 \mathrm{~g}$ for raw and extracted "cumari" pepper, respectively, which is equivalent to 1.77 and $1.73 \mathrm{mg} \mathrm{GAE} \mathrm{g}^{-1}$. These values are close to those obtained in this study for the in natura peppers independently of the solvent used.

According to Carvalho et al. (2014) the phenol content in peppers ranges from 70.70 - 99.48 $\mathrm{mg} \mathrm{GAE} / 100 \mathrm{~g}$, which is equivalent to $0.994-5.70$ $\mathrm{mg} \mathrm{GAE} \mathrm{g}^{-1}$ in the dried form. These values are also in agreement with this study.

Although there is no standard value per type of food or even according to the type of solvent and duration of extraction, normally the higher the phenolic content in a sample, the higher the antioxidant activity, as these phenolics are substances that act as antioxidants.

As for the extraction time of the total phenols, there was no significant difference between the extractions performed for 6 and $24 \mathrm{~h}$ (Table 3), independent of the sample treatment. This indicates that it is possible to maximally extract phenolic compounds in a relatively brief. Bergamaschi (2016) describes the importance of optimizing the extraction process in relation to time and temperature and pressure and temperature. By optimizing these parameters, the extraction process efficiency is sought in economic terms.

Table 3. Effect of extraction time on total phenol content expressed as milligrams of gallic acid equivalents per gram (mg GAE/g), according to a mean obtained from the seven solvents.

\begin{tabular}{ccc}
\hline Tratament & $6 \mathrm{~h}$ & $24 \mathrm{~h}$ \\
\hline In natura $^{\text {ns }}$ & $1.34 \mathrm{a}$ & $1.39 \mathrm{a}$ \\
Dry $^{\text {ns }}$ & $3.92 \mathrm{a}$ & $4.21 \mathrm{a}$ \\
Oil $^{\text {ns }}$ & $1.57 \mathrm{a}$ & $2.06 \mathrm{a}$ \\
vineger $^{\text {ns }}$ & $0.49 \mathrm{a}$ & $0.47 \mathrm{a}$ \\
\hline
\end{tabular}

${ }^{* *}, *$, ns Significant difference at $1 \%$ probability level $(\mathrm{p}<0.01)$, at $5 \%$ probability level $(0.01<\mathrm{p}<0.05)$ and no-significant difference by analysis of variance; Same letters in the same column do not differ $(\mathrm{p}>0.05)$ by Tukey test.

There was no significant difference in the antioxidant activity (Table 4) of the in natura as well as oil and vinegar preserved peppers, independent of the solvent used. However, the antioxidant activity of the dried peppers extracted with acetone p.a. and ethanol p.a. was comparable, with a mean of value of $23.38 \%$. This value was much lower than that of the other solvents used, which showed no statistical differences between them and a mean value of $71.38 \%$. This low antioxidant activity is probably due to the low extraction yield of phenols (Table 01) observed with the two solvents.

Santas et al. (2008) studied the antioxidant activity of two onion varieties and obtained comparable results. Extractions performed with acetone and ethanol at $100 \%$ resulted in the lowest yield of phenolic compounds $(\mathrm{p}<0.05)$. In this study, except for extraction of the samples preserved in oil, distilled water showed a good extraction solvent, confirming the hydrophilic characteristics of some phenolic compounds.

Table 4. Antioxidant activity (\%) in 7 solvents subjected to treatments: Pepper in nature; dry pepper; pepper in oil preserves; pepper vinegar preserves, obtained from the mean of Capsicum chinense and Capsicum ssp.

\begin{tabular}{|c|c|c|c|c|}
\hline Solvent & in natura $^{\mathrm{ns}}$ & dry $^{* *}$ & oil $^{\mathrm{ns}}$ & vinegar $^{\mathrm{ns}}$ \\
\hline water & $19.14 \mathrm{a}$ & $74.55 \mathrm{a}$ & $20.77 \mathrm{a}$ & $18.13 \mathrm{a}$ \\
\hline ethanol p.a & $30.10 \mathrm{a}$ & $23.40 \mathrm{~b}$ & $20.81 \mathrm{a}$ & $19.42 \mathrm{a}$ \\
\hline ethanol $50 \%$ & $31.90 \mathrm{a}$ & $66.36 \mathrm{a}$ & $33.09 \mathrm{a}$ & $20.96 \mathrm{a}$ \\
\hline acetone p.a & $30.34 \mathrm{a}$ & $23.07 \mathrm{~b}$ & $33.21 \mathrm{a}$ & $29.40 \mathrm{a}$ \\
\hline acetone $50 \%$ & $32.62 \mathrm{a}$ & $78.27 \mathrm{a}$ & $15.04 \mathrm{a}$ & $24.77 \mathrm{a}$ \\
\hline methanol p.a & $41.77 \mathrm{a}$ & $60.93 \mathrm{a}$ & $21.97 \mathrm{a}$ & $23.34 \mathrm{a}$ \\
\hline methanol $50 \%$ & $34.22 \mathrm{a}$ & $76.76 \mathrm{a}$ & $19.89 \mathrm{a}$ & $20.12 \mathrm{a}$ \\
\hline
\end{tabular}

${ }^{* *, *, \text { ns }}$ Significant difference at $1 \%$ probability level $(\mathrm{p}<0.01)$, at $5 \%$ probability level $(0.01<\mathrm{p}<0.05)$ and no-signicant difference by analysis of variance; Same letters in the same column do not differ $(\mathrm{p}>0.05)$ by Tukey test.

Boeing et al. (2014) observed that samples of cranberry and strawberry extracted with mixtures of ethanol/water $(50 / 50, \mathrm{v} / \mathrm{v})$, acetone/water/acetic acid (50/49.5/0.5, v/v), and acetone/water (50/50, $\mathrm{v} / \mathrm{v}$ ) showed the highest antioxidant capacity, which partially in agreement with our results shown in Table 04. However, in this study, distilled water showed no significant difference compared to the remaining solvents used and (except for the acetone and ethanol p.a. for the dry pepper, which presented 
values below the others), therefore, may even be considered as the ideal extraction solvent because of its high efficiency and low-cost.

The analysis of the antioxidant activity of the Capsicum chinense and Capsicum spp peppers (Table 5) showed that the dried form of both peppers exhibited similar antioxidant activity with a mean value of $57.62 \%$. The samples preserved in vinegar also presented comparable results among themselves (mean value of $22.31 \%$ ); however, the antioxidant activity was 2.6-fold lower than the dry. According to the observations by Santas et al. (2008), higher total phenolic contents lead to higher antioxidant activity. For the in natura peppers, we observed that the antioxidant activity of the Capsicum chinense (bode vermelho) was higher than that of the Capsicum spp pepper (de cheiro); however, when preserved in oil, the results were in reverse, which was probably due to the polarity of the solvent.

Table 5. Percentage antioxidant activity of capsicum chinense and capsicum spp peppers, according to a mean obtained from the seven solvents.

\begin{tabular}{ccccc}
\hline Peppers & ${\text { in } \text { natura }^{*}}$ & dry $^{\mathrm{ns}}$ & oil $^{* *}$ & vinegar $^{\mathrm{ns}}$ \\
\hline Capsicum chinense & $39.43 \mathrm{a}$ & $58.36 \mathrm{a}$ & $15.26 \mathrm{~b}$ & $21.64 \mathrm{a}$ \\
Capsicum spp & $23.46 \mathrm{~b}$ & $56.90 \mathrm{a}$ & $31.83 \mathrm{a}$ & $22.98 \mathrm{a}$ \\
\hline${ }^{* * * *, n^{*}}$ Significu
\end{tabular}

${ }^{* *},{ }^{*}$, ns Significant difference at $1 \%$ probability level $(\mathrm{p}<0.01)$, at $5 \%$ probability level $(0.01<\mathrm{p}<0.05)$ and no-signicant difference by analysis of variance; Same letters in the same column do not differ $(\mathrm{p}>0.05)$ by Tukey test.

A possible explanation for the high antioxidant activity value of the dried peppers may be the quantity of total phenolics present per gram of dried pepper (4.90 mg GAE/g) compared to the mean content of phenolics in peppers that were preserved in vinegar $(0.49 \mathrm{mg} \mathrm{GAE} / \mathrm{g})$.

Melo et al. (2011) quantified phenolic compounds and antioxidant activity of "bode," "cumari," and "chili" peppers that were dried and observed that the phenolic content differed greatly between these peppers. The values obtained were 294.00, 347.12, and 1,328.28 mg GAE/100 $\mathrm{g}$ for "bode," "cumari," and "chili" peppers with an antioxidant capacity range of $60-70 \%$. Costa et al. (2010) reported that the antioxidant potential of peppers is not only related to the total phenolic concentrations but also to the content of capsaicinoids in the pepper, which can donate electrons to the DPPH radical and stabilize it. Furthermore, data shows (Table 4) that the antioxidant activity of the peppers dry (except for acetone and ethanol p.a) was approximately $60 \%$, which is close to the results obtained by Melo et al. (2011) in their study of "bode," "cumari," and "chili" peppers.

Therefore, it is evident that drying increased the total phenolic content of all peppers investigated in numerous studies compared to the other processing treatments. However, this effect is due to the concentration of the component per gram of pepper, as observed by Moresco (2013).

Zhang and Hamauzu (2003) studied the phytochemicals in green, red, and yellow peppers and observed that the green peppers had the highest phenolic content compared with red and yellow peppers. In their antioxidant activity assay, the green pepper also showed the highest activity of the phenolic extracts of all three colored peppers. A direct correlation between total phenols and antioxidant activity was also observed by Santas et al. (2008) and Boeing et al. (2014). Although the peppers in this study ("bode vermelho" and "de cheiro") belong to different species, our results are in disagreement with those of the previous studies cited above since as the Capsicum chinense "bode vermelha" pepper showed higher total phenol content than the green colored Capsicum ssp "de cheiro" pepper.

Regarding the effects of maturation, Carvalho et al. (2014) found that all the genotypes in their study had significantly increased $(\mathrm{p} \leq 0.05)$ phenolic content when the plants were mature, except for one genotype, which showed a decrease of $54.79 \%$ in phenolic content of mature plants compared to the ones at immature stage. It is possible that the increase in phenolic content of mature fruits is owing to pigments that provide colorful appearance to food or secondary products of the metabolism, which are normally derived from defensive reactions of the plants against adverse environmental stimuli (Silva et al., 2010; Cazarin et al., 2014).

Frary et al. (2008) analyzed 29 pepper cultivars and observed that the phenolic content ranged from 607-2,724 $\mathrm{mg} \mathrm{kg}^{-1}$, signifying a 4.5 fold difference between varieties while the antioxidant activity showed a 7.4-fold variation between the lowest and the highest value obtained in the experiments $(2.57-18.96$ Trolox $\mathrm{mmol} / \mathrm{kg})$. This result led the authors to conclude that genetic improvement and mapping of the nutritional content of pepper can be performed and thereby led to the development of a cultivar with a high content of phytochemicals and antioxidant activity. 
Red peppers of the genus Capsicum have been extensively studied as a new source of natural antioxidants. Some studies show that antioxidant properties of these peppers are attributable to the presence of capsaicin and other bioactive compounds. Antioxidants are of extreme importance because they perform different activities in foods via various mechanisms including the breakdown of free radicals that are responsible for deleterious oxidation reactions (MORAES et al., 2012). In addition to their positive action on the endogenous metabolism of the body mediated by delaying or decreasing the formation of free radicals, antioxidants help prevent diseases associated with aging and cardiovascular risks. Furthermore, they also play a role as food preservatives by inhibiting oxidation reactions responsible for food degradation (LOBO et al., 2010). Therefore, the positive benefits of their application justify studying the extraction, quantification of phenolic compounds, and determination of antioxidant activity of fruits from plants with a short life cycle such as peppers.

\section{CONCLUSIONS}

Highest phenolic content and antioxidant activity were obtained from in natura and dried peppers. It is possible to perform the extraction in a relatively brief time to measure the phenolic compounds.

Distilled water was the most efficient solvent for the extraction of the total phenolics used in the determination of antioxidant activity of the pepper samples investigated this study.

The Capsicum chinense pepper ("bode vermelha") had an overall higher phenolic content than the "de cheiro" pepper (Capsicum ssp).

\section{ACKNOWLEDGEMENTS}

The authors thank the Instituto Federal do Triângulo Mineiro - Campus Uberlândia for the use of laboratory and reagents required to research and CNPq for student support.

RESUMO: A proposta deste trabalho foi avaliar a extração e quantificação de compostos fenólicos totais e a atividade antioxidante de duas espécies de pimentas processadas por quatro diferentes métodos (in natura, seca, conserva em vinagre e conserva em óleo). Foi verificado a eficiência de extração de fenólicos totais de sete solventes (água destilada, etanol p.a, etanol $50 \%$, metanol p.a, metanol $50 \%$, cetona p.a e cetona $50 \%$ ). Foram realizadas análises de fenólicos totais, utilizando o método de Folin Ciocalteu e ácido gálico para obtenção da curva padrão com leitura de absorbância $650 \mathrm{~nm}$. A atividade antioxidante foi determinada por meio de método espectrofotométrico, utilizando o reagente 2,2-difenil-1-picril hidrazil (DPPH). Não foram observadas diferenças significativas nos dois tempos de extração 6 e $24 \mathrm{~h}$. Para as amostras preservadas em vinagre, não foram observadas diferenças significativas entre os solventes utilizados para a extração. A pimenta Capsicum chinense apresentou a maior quantidade de compostos fenólicos em todos os tratamentos quando comparada à pimenta de cheiro, exceto quando conservada em óleo. Para a pimenta seca, o menor valor médio de extração de fenólicos totais foi obtido com etanol a 99,5\% (p.a) e acetona p.a-ACS 99,5\% (p.a), que diferiu das pimentas conservadas em óleo. A análise da atividade antioxidante das pimentas Capsicum chinense e Capsicum spp não apresentou diferença significativa $(\mathrm{p}>0,05)$ quando comparadas às amostras secas ou conservadas com vinagre. No entanto, a amostra de pimenta "Capsicum chinense" in natura apresentou maior atividade antioxidante do que as amostras conservadas em óleo. Pode-se considerar, pelos resultados experimentais, que as pimentas em estudo, principalmente na forma in natura e dessecada são boas fontes de antioxidantes naturais.

PALAVRAS-CHAVE: Análise química. Pimenta.

\section{REFERENCES}

BERGAMASCHI, K. B. Extração, determinação da composição fenólica e avaliação do potencial de desativação de espécies reativas de oxigênio e da atividade anti-inflamatória de resíduos de amendoim, pimenta-rosa e pimenta-do-reino. 2016. Tese (Doutorado em Ciência e Tecnologia de Alimentos) - Escola Superior de Agricultura Luiz de Queiroz, University of São Paulo, Piracicaba, 2016. https://doi.org/10.11606/T.11.2016.tde-22062016-170703 
BERTOLDI, M. C. Atividade antioxidante in vitro da fração fenólica, das oleorresinas e do óleo essencial de pimenta rosa (Schinus terebinthifolius Raddi). 2006, 96 p. Dissertação (Mestrado em Ciência e Tecnologia de Alimentos) - Universidade Federal de Viçosa - UFV, Viçosa, MG, 2006.

BOEING, J. S., BARIZÃO, E. O., COSTA e SILVA, B., MONTANHER, P, F., ALMEIDA, V. C., VISENTAINER, J. V. Evaluation of solvent effect on the extraction of phenolic compounds and antioxidant capacities from the berries: application of principal component analysis. Chemistry Central Journal, v. 8, n. 1, [on line], 2014. https://doi.org/10.1186/s13065-014-0048-1

BRAND-WILLIAMS, W., CUVELIER, M. E. BERSET, C. Use of a free radical method to evaluate antioxidant activity. Lebensmittel Wissenscharft and Technologies, v. 28, n. 1, p. 25-30, 1995. https://doi.org/10.1016/S0023-6438(95)80008-5

CARVALHO, A. V., MATTIETTO, R. A., RIOS, A. O., MORESCO, K. S. Mudanças nos compostos bioativos e atividade antioxidante de pimentas da região amazônica. Pesquisa Agropecuária Tropical, v. 44, n. 4, p. 399-408, 2014. https://doi.org/10.1590/S1983-40632014000400004

CAZARIN, C. B. B., SILVA, J. K., COLOMEU, T. C., ZOLLNER, R. L., MARÓSTICA JUNIOR, M. R. Capacidade antioxidante e composição química da casca de maracujá (Passifl ora edulis) Ciência Rural. v. 44, n. 9, p.1699-1704, 2014. https://doi.org/10.1590/0103-8478cr20131437

COSTA, L. M.; MOURA, N. F.; CRISTIANE MARANGONI, C.; MENDES, C. E.; TEIXEIRA, A. O. Atividade antioxidante de pimentas do gênero Capsicum. Ciência e Tecnologia de Alimentos [online], v.30, suppl.1, p. 51-59, 2010. https://doi.org/10.1590/S0101-20612009005000004

DALLAQUA, B., DAMASCENO, D. C. Comprovação do efeito antioxidante de plantas medicinais utilizadas no tratamento do Diabetes mellitus em animais. Revista Brasileira de Plantas Medicinais, v. 13, n. 3, p. $367-$ 373, 2011. https://doi.org/10.1590/S1516-05722011000300017

FRARY, A., ALI KECXELI, M., ÖKMEN, B. Ö., SXIGVA, H., YEMENICIOGLU, A., DOGANLAR, S. Water-soluble Antioxidant Potential of Turkish Pepper Cultivars. Hortscience, v. 43, n. 3, p. 631-636, 2008. https://doi.org/10.21273/HORTSCI.43.3.631

HEKIMI, S., LAPOINTE, J., WEN, Y. Taking a "good"' look at free radicals in the aging process. Trends in Cell Biology. v. 21, n. 10, p. 569-576, 2011. https://doi.org/10.1016/j.tcb.2011.06.008

LAMBETH, D., NEISH, A, S. Nox Enzymes and New Thinking on Reactive Oxygen: A Double-Edged Sword Revisited, Annual Review of Pathology: Mechanisms of Disease , v. 9, p. 119-145, 2014. https://doi.org/10.1146/annurev-pathol-012513-104651

LOBO, V., PATIL, A., PHATAK, A., CHANDRA, N. Free radicals, antioxidants and functional foods: Impact on human health. Pharmacognosy Review, v. 4, p. 118-126, 2010. https://doi.org/10.4103/0973-7847.70902

LUTZ, D. L., FREITAS, S. C. Valor nutricional. In: RIBEIRO, C. S. C. et al. Pimentas Capsicum. Brasília: Embrapa Hortaliças, p. 31-37, 2008.

MEDA, A., LAMIEN, C. E., ROMITO, M., MILLOGO, J.; NACOULMA, O. G. Determination of the total phenolic, flavonoid and proline contents in Burkina Fasan honey, as well as their radical scavenging activity. Food Chemistry, v. 91, p. 571-577, 2005. https://doi.org/10.1016/j.foodchem.2004.10.006

MELO, C. M. T., COSTA, L. A., BONNAS, D. S., CHANG, R. (2011). Compostos fenólicos e capacidade antioxidante de pimentas Capsicum chinense (bode), Capsicum baccatum variedade praetermissum (cumari) e Capsicum frutescens (malagueta). Enciclopédia Biosfera, v. 7, p. 1-6, 2011. 
MENSOR, L. L., MENEZES, F. S, LEITAO, G. G., REIS, A. S., DOS SANTOS, T. C., COUBE, C. S., et al.. Screening of Brazilian plant extracts for antioxidant activity by the use of DPPH free radical method.

Phytotherapy Research, v. 15, p. 127-130, 2001. https://doi.org/10.1002/ptr.687

MORAIS, S. A. L. AQUINO, F. J. T., NASCIMENTO, P. M., NASCIMENTO, E. A., CHANG, R. Compostos bioativos e atividade antioxidante do Café Conilon submetido a diferentes graus de torra. Quimica Nova. v. 32, n. 2, p. 327-331, 2009. https://doi.org/10.1590/S0100-40422009000200011

MORAES, L. P., PAZ, M. F., ARGANDOÑA, E. J. S., SILVA, L. R., ZAGO, T. O. Compostos Fenólicos e Atividade Antioxidante de Molho de Pimenta "Dedo-de-Moça" Fermentado. Biochemistry and Biotechnology Reports, v. 1, n. 2, p. 33-38, 2012. https://doi.org/10.5433/2316-5200.2012v1n2p33

MORESCO, C.S. (2013). Potencial antioxidante, efeito do processo de secagem e extração de compostos bioativos de pimentas Capsicum. 2013. 92 f. Dissertação (Mestrado em Ciência e Tecnologia de Alimentos) Curso de pós-graduação em Ciência e Tecnologia de Alimentos, Universidade Federal do Rio Grande do Sul, Porto Alegre, 2013.

OLIVEIRA, A. C.; VALENTIM, I. B., FONSECA-GOULART, M. O., SILVA, C. A., BECHARA, E. J. H., TREVISAN, M. T. S. Fontes Vegetais Naturais de Antioxidantes. Química Nova, v. 32, n. p. 689-702, 2009. https://doi.org/10.1590/S0100-40422009000300013

OLIVEIRA, A. M. C. (2011). Caracterização química, avaliação da atividade antioxidante in vitro e atividade de pimentas do gênero Capsicum spp. Dissertação (Mestrado em Alimentos e Nutrição) - Curso de pós-graduação em Alimentos e Nutrição, Universidade Federal do Piauí, Terezina. 81f, 2011.

PAULA, J. A. M., REIS, J. B., FERREIRA, L. H. M., MENEZES, A. C. S., PAULA, J. R. Gênero Pimenta: aspectos botânicos, composição química e potencial farmacológico. Revista Brasiliera de Plantas Medicinais, v. 12, n. 3, p. 363-379, 2010. https://doi.org/10.1590/S1516-05722010000300015

PINTO, C. M. F., PINTO, C. L. O., DONZELES, S. M. L. Pimenta Capsicum: propriedades químicas, nutricionais, farmacológicas e medicinais e seu potencial para o agronegócio. Revista Brasileira de Agropecuária Sustentável (RBAS), v. 3, n. 2, p. 108-120, 2013.

SANTAS, J., CARBÓ, R., GORDON, M. H., ALMAJANO, M. P. (2008). Comparison of the antioxidant activity of two Spanish onion varieties. Food Chemistry, v. 107, n. 3, p. 1210-1216, 2008.

https://doi.org/10.1016/j.foodchem.2007.09.056

SILVA, F. A. S.; AZEVEDO, C. A. V. Versão do programa computacional Assistat para o sistema operacional Windows. Revista Brasileira de Produtos Agroindustriais, v. 4, n. 1, p. 71-78, 2002. https://doi.org/10.15871/1517-8595/rbpa.v4n1p71-78

SILVA, M. L. C., COSTA, R. S., SANTANA, A. S., KOBLITZ, M.G.B. Compostos fenólicos, carotenóides e atividade antioxidante em produtos vegetais. Semina: Ciências Agrárias, v. 31, n. 3, p. 669-682, 2010. https://doi.org/10.5433/1679-0359.2010v31n3p669

SWAIN, T., HILLIS, W. E., The phenolic constituents of Prunus domestica. The quantitative analysis of phenolic constitutents. Journal Science Food Agricuture, v. 10, n. 1, p. 63-68, 1959.

https://doi.org/10.1002/jsfa.2740100110

VALVERDE, R. M. V. (2011). Composição bromatológica da pimenta malagueta in natura e processada em conserva. Dissertação (Mestrado em Engenharia de processos de alimentos) Curso de pós-graduação em Engenharia de Alimentos, Universidade Estadual do Sudoeste da Bahia, Itapetinga, Bahia, , 54p, 2011. 
VELIOGLU, Y. S., MAZZA, G., GAO, L., OOMAH, B. D. Antioxidant Activity and Total Phenolics in Selected Fruits, Vegetables, and Grain Products. Journal of Agricultural and Food Chemistry, v. 46, n. 1 p. 4113-4117, 1998. https://doi.org/10.1021/jf9801973

ZHANG, D., HAMAUZU, Y. Phenolic compounds, ascorbic acid, carotenoids and antioxidant properties of green, redand yellow bell peppers. Journal of Food and Agriculture and Environment, v. 1, n. 2, p. 22-27, 2003. 